\title{
First year law students: the impact of changes to assessment regime on attainment
}

\section{Introduction}

The foregoing action research was undertaken because of concern with progression issues at the end of the first year of study on the LLB (Hons) degree at the University of Wolverhampton Law School, a post-1992 university with a widening participation agenda. Post-1992 institutions are former polytechnics in the United Kingdom that gained university status through the Further and Higher Education Act 1992. Widening participation in higher education forms part of the government education policy in the United Kingdom and Europe and is a strategic objective of the Office for Students and forms part of its Access and Participation plan. An aim of the policy is to increase the proportion of students entering higher education from under-represented groups including students from lower income families, people with disabilities and some ethnic minorities. The University of Wolverhampton is an English-speaking university based in Central England with the majority of students being drawn from the local area and the vast majority of students speaking English as their first language.Full time LLB Honours students at the University of Wolverhampton undertake six modules during each academic year, completing eighteen modules over a three-year period. Each module carries an equal weighting of 20 credits, with three modules being studied in each of the two semesters during an academic year. Part time students study the same modules on a pro rata basis over a period of between four and six years. Students achieving 100 credits or more from the possible 120 credits are awarded a 'PRO' code at the end of the academic year, entitling full time progression into year two. The number of students awarded a 'PRO' code at the end of the 2014/15 year had fallen by $8.3 \%$ from the year ending 2013/14, putting progression rates on a falling trajectory. A gender 
attainment gap (where females outperformed males) and a gap based on ethnicity (where white students outperformed UK-domiciled black and minority ethnic (BME) students) was also identified. Attainment for the purposes of this study may be defined as a student achieving a minimum pass rate of $40 \%$ enabling the student to be awarded 20 credits for that module. Retaining students at the end of the first year of study is an even greater challenge for courses at widening participation institutions where students will often have lower entry qualifications. This is evidenced by figures produced by Higher Education Statistics Agency which showed just $1.2 \%$ of law undergraduates with the highest entry qualifications had left Higher Education during academic year 2015/16 whereas 7.7\% of those with less than 160 UCAS (The Universities and Colleges Admissions Service) tariff points (2016 tariff) had left. Assessment methods can largely determine what and how students learn (Rowntree 1977), although a complex series of factors impact upon student attainment, assessment is one of those factors (Thomas 2002, 423 - 442). This study is limited to observing the results of a change to one of these factors; as, subject to University regulations, a student's inability to progress on the course will be determined not just by his/her choice, but by whether the regulations allow him/her to stay and progress.

The first year LLB students entering the Law School were subjected to an assessment regime within their first year consisting almost entirely of examinations and concerns were raised within the Law School that this approach was not offering the students the best opportunity to progress.

A change of assessment regime was undertaken to ascertain whether this would have any impact upon module performance, enabling more students to obtain sufficient credits to progress to the second year of study. The resulting data was analysed to identify whether moving away from assessment via examination only would have an impact upon student 
attainment and, by extension, upon progression rates.

The study considers the different outcomes achieved when the assessment of a module is changed. The study specifically considers the impact of a change of assessment regime on the results of two core first year modules. The study also analyses the data to identify patterns in pass rates in specific groups based on gender and ethnicity in order to establish whether a change in assessment type has any impact on the gender and ethnicity attainment gap.

\section{Review of literature}

A module needs to be assessed to evaluate whether the learning outcomes for the module and the course have been met. However, a review of the literature shows that the method and timing of assessment may have implications for the success of the student and the aim of the educator is to enable the student to achieve the best possible outcome. It has been noted that, "students have to be assessed and success or failure will have obvious consequences for their self-esteem.” (Hussey and Smith 2010, 162). It is known that law students experience elevated levels of psychological distress, beginning in the first year of law school (Field, Duffy and Huggins 2013, 15 - 25). Studies have been carried out to investigate the impact that anxiety may have on students when undertaking examinations and it has been established that this type of anxiety can impact negatively on attainment for higher education students (Hembree 1998, 47 - 77) (Richardson, Abraham and Bond 2012, 353 - 387). With this in mind, the balance of assessment type and timing becomes crucial in avoiding stress and achieving maximum success.

Students who engage with the module content, rather than simply learning for the assessment, are more likely to be successful in the assessment as the understanding will be greater. Ecclestone (2002) found that student approaches to learning were influenced by assessment. 
Ramsden $(1992,67,182)$ maintains that "assessment plays a key role in determining the quality of student learning" and that "if students perceive that their learning will be measured in terms of reproducing facts" then they will adapt their learning accordingly and, as a result, this will "prevent understanding from being reached." Taras and Davies (2012, 51 - 61) agreed that assessment can have a negative impact 'on future prospects and the links to perceived personal worth' and cite Broadfoot $(2007,2008)$ and Stobart (2008) in support of the view that the summative function of assessment added to the negative impact.

Fitzgerald $(2008,60-84)$ cites the opinions of students that examinations do not provide an opportunity to demonstrate their knowledge and are not an accurate measure of ability. In a review of the literature relating to coursework and examinations conducted by Richardson (2015, 439 - 455) it was concluded that not only do students prefer to be assessed by either coursework alone (Chamorro-Premuzic et al 2005) (Furnham et al 2008) or a combination of coursework and examination, but that students also achieve higher marks when not assessed solely by examination. Hussey and Smith $(2010,162)$ identify that the danger of a course assessed largely or only by final examination is that in large groups, "only the final examinations reveal something of the truth, by which time it is too late to help." In addition to this, students are likely to leave any preparation work until a week before the examination, rather than pacing their learning (Rust 2002, $145-158$ ).

Following a review of the available literature relating to the use of examination or coursework in which he noted the findings of Lindsay and Paton-Saltzberg (1987, 213 - 227), and Gibbs, Lucas, and Simonite (1996, 261 - 273) that there was a negative relationship between class size and student attainment; Richardson (2015, 439 - 455$)$ concluded that "the adoption of assessment by coursework appears to attenuate the effect of class size, and the exclusive adoption of assessment by coursework appears to eliminate the effect altogether." 
Further "it is also clear that class size exerts an independent negative influence on perceived student learning" Chapman and Ludlow $(2010,117)$. The class sizes for the modules considered in this study average 120 students for lectures and 30 for seminars. Class size was a factor taken into consideration when deciding to change the assessment type; Gibbs, Lucas and Spouse $(1997,311$ - 318) found that in a study of nursing modules with large student cohorts, "the greater the proportion of coursework, the better the students performed." Coursework was therefore considered to be beneficial both in terms of improving student learning and improved attainment.

The position of the assessment in the overall module also plays a crucial role. It has been observed by Bennett (2000, 167 - 174) that, “An assignment set early in the course may well be providing both summative and formative assessment. Thus it has the potential for useful feedback, but also contributes to the overall marks for the course," whereas Weaver (2007, 379 - 394) noted that "assessment practices which focus on end-of-module assessments cannot effectively help to develop knowledge and skills."

By changing from examination to coursework that is assessed at an earlier stage, the student has the opportunity to utilise feedback to inform learning, and the subsequent assessment, in other modules. Brown and Glasner (2003) identified that deficient areas could be improved by the provision of timely feedback which could be more easily given when a module was assessed using coursework than when assessed by examination. A study by Heywood (2000) found that lack of feedback increased anxiety. Where a decision has been made to assess by coursework rather than examination, a continuously assessed portfolio presents a range of benefits. Assessing a module by a portfolio, requiring regular small submissions from an early stage in the module, presents the opportunity for the tutor to provide timely feedback which in turn assists students in preparation of coursework in other modules, improving 
performance in those modules and consequently having a positive impact on progression.

Use of a portfolio assessment can improve student success as a result of greater student engagement in the subject matter. It has been found that not only do students feel part of the assessment process when a portfolio is utilised but also that 'portfolio assessment appeared to empower students.'(McDonald 2011, 335 - 347)

In relation to gender, in a literature review conducted by Richardson $(2015,439$ - 455) it was concluded that the literature found that although women generally achieve higher results than men in coursework and examination, both groups are generally more successful in coursework. It has also been shown that women prefer continuous assessment methods. (Furnham and Chamorro-Premuzic 2005a, 69 - 90, 2005b, 1968 - 1994)

In relation to the BME attainment gap, it was further concluded that, "White students tend to produce better marks than students from other ethnic groups in both coursework and examinations, but students from all ethnic groups tend to obtain higher marks in coursework than in examinations." (Richardson 2015, 439 - 455). The results of this study highlight not just the problem of differing pass rates between assessment types but also the attainment gap which exists between gender and BME background and the impact that assessment type has on the gap. As this course has a majority of BME students, this impacted upon the choice to incorporate more coursework, although the attainment gap cannot be attributed solely to assessment types, research does suggest that it may play a part (Ridley 2007, 3 - 13). Studies have established that there is an identifiable link between a student's approach to learning, assessment type and achievement. (Entwistle and Peterson 2004, 407 - 428) (Lizzio, Wilson and Simons 2002, 27) (Marton and Saljo (1976), 4 - 11) (Struyven, Dochy and Janssens 2005,325 - 341). The use of a surface approach (Biggs 1979, 281 - 394) to learning has a negative impact on assessment success (Diseth 2003, 143 - 155) (Diseth and Martinsen 2003, 
195). The surface approach tends to result in a student rote learning selected information in order to pass the examination (Scouller 1998, 453 -472). However, it has been shown that there is a positive effect on assessment success where the student engages in a deep approach to learning (Roma, Cuestas and Fenollar 2008, 127 - 138). Research tends to support the view that students employ surface approaches to examination preparation (Biggs 1973, 157 167) (Ramsden 1992) and deeper approaches to coursework assessments (Thomas and Bain 1984, 227 - 240). Further, in relation to portfolios the study of Segers, Gijbels, and Thurlings (2008, 35 - 44) showed through correlational analyses that students who perceived a portfolio assessment as stimulating their learning and being motivating and who reported to use the feedback they received on the portfolio assessment were more inclined to use a deep approach.” (Baeten et al 2010, $243-260)$.

\section{Methodology}

The study took place in a Law School in a post-1992 widening participation institution. . The study was undertaken using the concept of action research. A project was designed to determine the impact of a change in assessment type on the overall pass rates of specific first year modules. The ethos of the study was that

\footnotetext{
"the fundamental purpose of pedagogical action research is to systematically investigate one's own teaching/learning facilitation practice with the dual aim of modifying practice and contributing to theoretical knowledge." (Norton 2009, 15 - 16)
}

Due to the problems with progression outlined above, several modules were identified as potential areas for a change of assessment type and two of these modules have been involved in this action research study. A change to assessment regime was implemented. Following the change to assessment by coursework or portfolio, quantitative data was analysed and 
reflected upon by the authors. The data was gathered over a four-year period from 2013 to 2017 and related to the number of students who passed the two modules considered within the academic year. Both modules form part of various degree programmes and for the purposes of this study the data relating to those students studying LLB (Hons) was extrapolated for analysis.

According to data compiled by the Higher Education Academy (HEA) $(2014,27)$, black and minority ethnic (BME) students studying Law amounted to $29 \%$ of students which, according to the HEA, is a notable over-representation as compared to the presence of BME students in the sector overall. There is a much greater variation in the student body on the LLB at this institution in terms of ethnicity than at many other UK Higher Education institutions. The percentage of BME students on the course is consistently high, with ethnicity across the four years of the study recorded as follows:

BME: $66.16 \%$ average, with a range of $61.73 \%$ to $69.49 \%$

White: $28.79 \%$ average, with a range of $25 \%$ to $33.33 \%$

Not known: $5.05 \%$ average, with a range of $2.94 \%$ to $8.54 \%$. Further data on the composition of the student body may be found in the appendix.

As the BME students at this institution account for an average of $66.16 \%$ of the total number during the period of the study, it might be expected that this difference would negate or even reverse the attainment gap. However, it does not do so, despite BME students making up the majority of the student cohort and white students being consistently in the minority. Across the four years under consideration, the number of students enrolled on each module averaged 157, with a range of 134 to 177 students. The majority of students were female, averaging $57.96 \%$ of the total number, with a range of $52.44 \%$ to $62.59 \%$. There was a 
considerable number of mature students over the age of 21 in the sample, given that only $61.3 \%$ of the students on average were under the age of 21 , with a range of 53.7 to $65.85 \%$ overall.

\section{Historical assessment regime}

This study considers two different first year modules. Tort Law (4LW005) is a module which is studied as a core at year one of the LLB (Hons) degree. In academic years 2013/2014 and 2014/2015, the module was assessed by an unseen examination at the end of the semester, representing $100 \%$ of the module credits.

English Legal System and Practice (4LW006) was a year one core module on the LLB (Hons) degree. In academic year 2013/2014, the module was assessed by a case study worth $25 \%$ of the module credits and a final seen examination worth the remaining $75 \%$ of the module credits. In 2014/2015, the module was assessed by a single seen examination at the end of the module worth $100 \%$ of the credits.

The sample size ranged from 134 to 177 students, depending on the number of students initially sitting or resitting a module in any given year. The data gathered relates to all LLB (Hons) students registered on the module and undertaking an assessment within each complete academic year.

\section{The rationale for changing the assessment regime}

Apart from the 25\% case study in 2013/2014 as part of the module 4LW006 (English Legal System and Practice), all assessments were undertaken by examinations in semester one. The impact of this was that the students were not accustomed to submitting written coursework and were not assessed fully (13/14) or at all (14/15) until January of the first year of study. Taking into consideration the four-week marking period of these assessments, students were 
not able to access feedback on assessment performance until February of their first year at the beginning of semester two. It was felt that this was prohibitive to the students settling into academic studies and that the burden of an examination-heavy regime was too great. The change of assessment regime to reduce the amount of examination and increase coursework was considered as a positive change in terms of improving student's learning style, reduction in anxiety and allowing early access to feedback. Portfolios provide an additional benefit of early and periodic assessment with timely feedback.

\section{Changed assessment regimes}

A review of the LLB (Hons) course was undertaken and module content and assessment was considered. During this process, changes were made to both modules considered in this study. Under the University's quality procedures module leaders ensured that external examiners were consulted, the QAA Subject Benchmark Statement for Law (2015), which defines what can be expected of a graduate in the subject, in terms of what they might know, do and understand at the end of their studies, was followed and that all learning outcomes for the module were met so that the resulting assessment was at least as rigorous in its challenge to the students. Learning outcomes requiring for example problem solving, application of law and legal knowledge may just as easily be met through coursework as through examination.

Tort Law (4LW005) underwent a minor module modification process whereby the assessment was changed to $100 \%$ coursework, to be submitted at the end of the module.

The module 4LW006, English Legal System and Practice, was deleted during the course revalidation process and replaced with a new module, Professional Development and Skills (4LW014). The content from the deleted module was subsumed into the new module with emphasis upon the skills element of the previous content. This module was 'double-badged' 
with the University's internal Enterprise and Employability Award (Bronze), which meant that students successfully completing the module would be awarded both the module credits and the bronze award.

The rationale for changing the assessment regime of this module was that assessing the students by way of examination in January meant that lecturers were unaware of the students' abilities and students were unable to ascertain whether they were working at the correct standard because of lack of opportunity for feedback. Considering difficulties with attainment, it was felt that students would benefit from submitting assessments at a much earlier stage, in smaller, more manageable portions at regular intervals. This would highlight any issues with struggling students within the first few weeks of the course and help with pacing of the learning (Rust 2002, 145 - 158). As evidenced by the research, this form of assessment could also encourage a deeper learning style which would be beneficial to the student. As a result of this revalidation, the assessment for the module was set as a portfolio comprising a small case study, a CV, a career action plan and a skills analysis. The use of an incremental submission pattern enabled the module team to provide early feedback, to recognise students in need of additional support and to ensure non-participating students were identified at an earlier stage. Feedback on each submission included elements of feedforward allowing the student to develop their academic acumen to improve future submissions.

\section{Findings}

The findings of this study confirm an increase in pass rates with the introduction of either a single written coursework assessment or a portfolio. The authors acknowledge that many factors will impact upon attainment and progression including the student's own motivation, self-efficacy, financial situation and failure to engage with peers, academic staff or the subject matter itself, (Brooman and Darwent 2012,19, 27). Variations in teaching, materials, 
attendance, entry qualifications, external commitments such as part time employment (Bone 2009, 222 - 245) (Claydon 2009, 269 - 283) and the availability of formative assessment will also impact upon the pass rate in ways that the simple pass rate data cannot explain. Whilst acknowledging the existence of the influence of these other potential factors, the results after a change of assessment type were as follows:

\section{Law of Torts}

In the module Law of Torts (4LW005), overall in-year pass rates were analysed to identify the number of students who were successful in the module. The two years when the module was assessed by examination yielded results on average $12 \%$ lower than for the two years when the module was assessed by coursework.

\section{English Legal System/Professional Development and Skills}

In the English Legal System and Practice module (4LW006), which was replaced in academic year 2015/16 by Professional Development and Skills (4LW014), results were analysed to obtain an average pass rate for two years prior to and two years following the introduction of a portfolio assessment. The introduction of a portfolio saw an average increase in the pass rate of $10 \%$.

During data analysis the authors identified that although an overall improvement of attainment was achieved by moving from examination to coursework, the gender attainment gap and BME attainment gap were preserved even within the attainment improvement. The difference in attainment between white and BME students, evidenced by the data examined, typically showed an attainment gap of between $4 \%$ and $5 \%$ in favour of white students during the period of the study

Again, we need to be cautious as to how much inference is drawn from these statistics given 
that the number of white male students is very low. For example, in the years which have been considered, the white male student population of the course was between $8 \%$ and $10 \%$ of all students. Having considered this data, a further analysis of the results was undertaken according to male and female students and ethnic background.

Table 1 Tort 4LW005

Table 2 English Legal System 4LW006/Professional Development and Skills 4LW014

In our sample, we found that BME students were outperformed by white students overall. This finding is consistent with the expected result that students from a white background typically may be expected to perform slightly better than BME students. (Barrow, Reilly and Woodfield 2009, 592).

In respect of the gender attainment gap, the results demonstrated that females outperformed males in both modules in all four academic years of the study, although the pass rates for both male and female groups improved.

The data was then analysed to assess whether the increase in attainment on these two modules, representing 40 credits of a possible 120 credits at level 4, had resulted in an increase in the number of students awarded a PRO code, enabling progression into level 5. In the two years prior to the assessment change there had been a decline in the number of students being awarded a PRO code. In the first year following the assessment change the number of PRO codes awarded increased by $5.8 \%$ and in the following year by a further $11 \%$.

One of the six core metrics of the TEF in relation to 'Learning Environment' is 'noncontinuation'. The TEF: year two at 5.10 explains that the non-continuation metric is "the proportion of students who start but do not continue their studies. Students are counted 
between their first and second year of study." With the implementation of the TEF retention remains a major concern due to the impact low continuation figures will have on the TEF rating of the institution. It will also be important to the Law School specifically once the TEF is extended to discipline level (Cureton et al 2017).

\section{Conclusion}

The results of this study identify the need for further research into whether certain assessment types or learning activities may assist in closing these gaps rather than simply raising attainment overall. A contemporaneous study at this University implemented by Cureton et al as part of the work that the institution is undertaking to significantly reduce its ethnicity based attainment gap, has achieved positive results by reviewing the quality of assessment briefs and holding assignment 'unpacking' sessions led by students in order to ensure that students are fully aware of what is being asked of them on the assessment brief. This was one of 13 Universities involved in the Paul Hamlyn Foundation 'What works?' (2017) student retention project. The findings on the BME attainment gap, which was virtually closed because of the trial, will be incorporated into any future curriculum changes as the programme is rolled out across the University.

The aim of this study was to assess whether the change of assessment regime had had any noticeable impact upon student performance. Student performance in coursework improved on examination results in previous years but it is acknowledged that this improvement is not necessarily solely due to the change in assessment alone. Whilst the authors acknowledge the impact of the previously listed variables on the module results, nonetheless it is felt that it is reasonable to infer that the change of assessment type is the primary reason for the improvement. This can be justified by considering the composition of the group of students from year to year and noting that there is parity across the four years in terms of gender, 
ethnicity, age and level of UCAS entry points as outlined earlier. Given that the data set is large with over 150 students per year, it was felt that this is a large enough sample group to enable the authors to acknowledge that a change in assessment type, together with the resultant improvement in learning style, is the most plausible significant factor in the consistent improvement in pass rates when examinations are replaced with coursework assessments. This is supported by the results of other research, with Gibbs noting that, "it is an almost universal experience of lecturers and students that coursework produces higher marks than examinations." (Gibbs and Lucas 1997, 183 - 192) Conversely, where the data set is very small such as with white males on this course at this institution, which amounts to $8 \%$ - $10 \%$ of all students on the LLB, a particularly strong or weak student in that category may influence the outcome significantly causing an anomalous result, as is evidenced by the results for white males.

As a post -1992 widening participation institution with a particularly high number of BME students it is hoped that other similar institutions may benefit from the findings - that subjecting the students to an examination heavy regime in their first year of legal education yields poorer results than offering a range of assessment types.

While this study has examined the data from modules which use coursework, examination and a portfolio it is acknowledged that other methods of assessing students, including oral presentations, open book examinations, writing a case note, group activities and mooting, will yield additional data which will inform curriculum design in light of the forthcoming Solicitors Qualifying Examination introduced by the Solicitors Regulation Authority. 


\section{REFERENCES}

Baeten, M., Kyndt, E., Struyven, K. and Dochy, F. 2010. "Using student-centred learning environments to stimulate deep approaches to learning: Factors encouraging or discouraging their effectiveness" Educational Research Review. 5: 243-260.

Barrow, B., Reilly, B. \& Woodfield, R. 2009. "The determinants of undergraduate degree performance: how important is gender?" British Educational Research Journal. 35(4): 575-597, 592.

Bennett, M. 2000. “Assessment to promote learning." The Law Teacher. 34(2): 167-174.

Biggs, J. B. 1979. "Individual differences in study processes and the quality of learning outcomes." Higher Education 8: 381-394.

Biggs, J.B. 1973. "Study behaviour and performance in objective and essay formats." Australian Journal of Education 17: 157-167.

Bone, A. 2009. "The twenty-first century law student." The Law Teacher Vol 43, No 3: 222 - 245.

Broadfoot, P. 2007. An Introduction to Assessment. New York/London: Continuum.

Broadfoot, P. 2008. "Assessment for learners: Assessment literacy and the development of learning power." In: Havnes, A and McDowell, L (eds) Balancing Dilemmas in Assessment and Learning in Contemporary Education: 213-24. New York/London: Routledge.

Brooman, S. and Darwent, S. 2012. "'Yes, as the Articles Suggest, I Have Considered Dropping out': Self-Awareness Literature and the First-Year Student." Studies in Higher Education 37 (1): 19-31. doi:10.1080/03075079.2010.490580.

Brown, G., \& Glasner, A. 2003. "Assessment matters in higher education: choosing and using diverse approaches." Buckingham: Open University Press, SRHE.

Chamorro-Premuzic, T., A. Furnham, G. Dissou and P. Heaven. 2005. "Personality and Preference for Academic Assessment: A Study with Australian University Students." Learning and Individual Differences. 15(4): 247.

Chapman, L. and Ludlow, L. 2010. "Can downsizing college class sizes augment student outcomes? An investigation of the effects of class size on student learning." The Journal of General Education. 59 (2): 105-23.

Claydon, L. 2009. "Engaging and motivating students: assessment to aid student learning on a first year core law module" The Law Teacher. 43(3): 269-283.

Cureton, D., Groves, M., Day, P,. \& Williams, C. 2017 "Supporting Student Success: Strategies for Institutional Change" University of Wolverhampton, http://www.phf.org.uk/wpcontent/uploads/2017/04/University-of-Wolverhampton-final.pdf accessed 01 October 2017

Diseth, $A^{\circ}$., \& Martinsen, $\varnothing .2003$. "Approaches to learning, cognitive style, and motives as predictors of academic achievement." Educational Psychology. 23(2): 195. 
Diseth, $A^{\circ}$., 2003. "Personality and approaches to learning as predictors of academic achievement." European Journal of Personality. 17(2): 143-155.

Ecclestone, K. 2002. "Learning Autonomy in Post-16 education: The Politics and Practice of Formative Assessment." New York: Routledge Falmer.

Entwistle, N., \& Peterson, E. R. 2004. "Conceptions of learning and knowledge in higher education: Relationships with study behaviour and influences of learning environments." International Journal of Educational Research. 41(6): 407-428.

Field, R., Duffy, J. \& Huggins, A. 2013."Supporting transition to law school and student well-being: The role of professional legal identity." The International Journal of the First Year in Higher Education. Vol 4(2): 15-25.

Fitzgerald, M. 2008. "Rite of passage: The impact of teaching methods on first year law students" The Law Teacher. 42(1): $60-84$.

Furnham, A., \& Chamorro-Premuzic, T. 2005a. "Personality, intelligence, and general knowledge." Learning and Individual Differences. 16(1): 79 - 90.

Furnham, A., \& Chamorro-Premuzic, T. 2005b. "Individual differences and beliefs concerning preference for university assessment methods." Journal of Applied Social Psychology. 35: 19681994.

Furnham, A., Christopher, A., Garwood, J. and Martin, N. G. 2008. "Ability, Demography, Learning Style, and Personality Trait Correlates of Student Preference for Assessment Method." Educational Psychology 28(1): 15.

Gibbs, G. \& Lucas, L. 1997. “Coursework Assessment, Class Size and Student Performance: 1984 94." Journal of Further and Higher Education. 21 (2): 183- 192.

Gibbs, G., Lucas, L. and Simonite, V. 1996. “Class Size and Student Performance: 1984-1994.” Studies in Higher Education. 21 (3): 261-273.

Gibbs, G., Lucas, L. and Spouse, J. 1997. "The effects of class size and form of assessment on nursing students' performance, approaches to study and course perceptions." Nurse Education Today. 17 (4): $311-318$.

Hembree, R. 1988. "Correlates, Causes, Effects, and Treatment of Test Anxiety." Review of Educational Research. 58 (1): 47-77.

Heywood, J. 2000. "Assessment in higher education: Student learning, teaching programmes and institutions." London: Jessica Kingsley.

Higher Education Statistics Agency. 2018. “Non-continuation: UK Performance Indicators 2016/17." Last updated $8^{\text {th }}$ March 2018. https://www.hesa.ac.uk/news/08-03-2018/non-continuation-tables

Hussey, T. \& Smith, P. 2010. "Transitions in Higher Education." Innovations in Education and Teaching International. 47(2): 155-164, 162. 
Lindsay, R. O., and Paton-Saltzberg, R. 1987. "Resource Changes and Academic Performance at an English Polytechnic." Studies in Higher Education. 12 (2): 213-227.

Lizzio, A., Wilson, K., \& Simons, R. 2002. “University students' perceptions of the learning environment and academic outcomes: Implications for theory and practice." Studies in Higher Education. 27(1): 27.

Marton, F., \& Saljo, R., 1976. "On qualitative differences in learning. Outcome and Process." British Journal of Educational Psychology. 46: 4-11.

McDonald, B. 2011. "Portfolio assessment: direct from the classroom." Assessment \& Evaluation in Higher Education 37,3: 335-347.

Norton, L., 2009."Action research in teaching \& learning: A practical guide to conducting pedagogical research in universities." Routledge: $x v-x v i$.

Paul Hamlyn Foundation. "What Works?” http://www.phf.org.uk/programmes/works/accessed 01 October 2017.

Quality Assurance Agency for Higher Education, Subject Benchmark Statement (LAW) (July 2015) http://www.qaa.ac.uk/publications/information-andguidance/publication?PubID=2966\#.We8DWf2Wy1s accessed 01 October 2017.

Ramsden, P. 1992. Learning to Teach in Higher Education. London \& New York: Routledge.

Richardson, J. T. E. 2015. "Coursework versus examinations in end-of-module assessment: a literature review." Assessment \& Evaluation in Higher Education. Vol. 40(3): 439 - 455.

Richardson, M., Abraham, C. and R. Bond. 2012. "Psychological Correlates of University Students' Academic Performance: A Systematic Review and Meta-analysis." Psychological Bulletin. 138 (2): 353-387.

Ridley, A. M. 2007. "Approaches to learning, age, ethnicity and assessment: implications for widening participation." Psychology Teaching Review. 13: 3-13.

Roma' n, S., Cuestas, P. J., \& Fenollar, P. 2008. "An examination of the interrelationships between self-esteem, others' expectations, family support, learning approaches and academic achievement." Studies in Higher Education. 33(2): 127-138.

Rowntree, D. 1977. “ Assessing students: How shall we know them?” Harper and Row.

Rust, C. 2002. "The impact of assessment on student learning - How can the research literature help to inform the development of departmental assessment strategies and learner-centred assessment practices?" Active Learning in Higher Education. Vol 3(2): 145-158.

Scouller, K. 1998. "The influence of assessment method on students' learning approaches: Multiple choice question examination versus assignment essay." Higher Education. 35(4): 453-472. 
Segers, M., Gijbels, D., \& Thurlings, M., 2008. “The relationship between students' perceptions of portfolio assessment practice and their approaches to learning." Educational Studies. 34(1): 35-44.

Stobart, G. 2008. "Testing Times: The Uses and Abuses of Assessment." New York/London: Routledge.

Struyven, K., Dochy, F. and Janssens, S. 2005. "Students' perceptions about evaluation and assessment in higher education: a review." Assessment and Evaluation in Higher Education. 30(4): $325-341$.

Taras, M., and Davies, M. S. 2012. "Perceptions and realities in the functions and processes of assessment" Active Learning in Higher Education. Vol 14(1): 51 - 61.

Thomas, L. 2012. "Student Retention in Higher Education: The Role of Institutional Habitus." Journal of Education Policy. 17 (4): 423-42. doi:10.1080/02680930210140257.

Thomas, P.R. and Bain, J.D. 1984. "Contextual dependence of learning approaches: the effects of assessments." Human Learning. 3: 227-240.

Weaver, M.R. 2007. "Do students value feedback? Student perceptions of tutors' written responses." Assessment \& Evaluation in Higher Education. 31(3): 379 - 394.

Woodfield, R. 2014. "Undergraduate retention and attainment across the disciplines". Higher Education Academy: 27.

https://www.heacademy.ac.uk/system/files/resources/undergraduate retention and attainment across the disciplines.pdf accessed 5th November 2017. 